\title{
PROFIL DAYA TAHAN OTOT, KEKUATAN OTOT, DAYA LEDAK OTOT, DAN KELENTUKAN PADA ATLET SENAM RITMIK KOTA BANDUNG MENURUT STANDAR KONI PUSAT
}

\author{
Dwi Putri Larasati ${ }^{1}$, Ronny Lesmana ${ }^{2}$, Yuni S. Pratiwi², Vita M. Tarawan² \\ ${ }^{1}$ Program Studi Ilmu Kedokteran Dasar, Fakultas Kedokteran, Universitas Padjadjaran \\ ${ }^{2}$ Departemen Anatomi, Fisiologi, dan Biologi Sel, Fakultas Kedokteran, Universitas Padjadjaran
}

\begin{abstract}
Physical fitness is the ability of an athlete to fulfill the physical activities that is needed for the sport without becoming weary. This is a very important thing that determines athlete's performance. The predominant component of physical fitness for rhythmic gymnastics are muscular endurance, muscle strength, power, and flexibility. The study aimed to gather information regarding the physical fitness profile of Bandung City rythmic gymnastic athlete before competing in Pekan Olah Raga Daerah Jawa Barat (PORDA Jabar) XI event in 2010.The descriptive study was conducted using survey method. Subjects consist of 9 female Bandung City rythmic gymnastic athletes. Muscle endurance, muscle strength, power, and flexibility were measured using appropiate tests and tools, and then grouped according to Standar KONI Pusat.The results of this study showed that most of the rythmic gymnastic athletes were in this categories: perfect for arms and shoulders muscle endurance, average for stomach muscle endurance, below standard for muscle strength of the hands, average for muscle strength of arms and shoulders, good and very good for muscle strength of the back, average for muscle strength of the legs, below average and average for arms and shoulders power, very good for legs power, and perfect for flexibility.As conclusion, the performance of Bandung City rythmic gymnastic athlete can be improved by increasing the training that are spesific for each of the physical fitness component.
\end{abstract}

Keywords: physical fitness, muscle endurance, muscle strength, power, flexibility, rythmic gymnastic 


\section{PENDAHULUAN}

Prestasi atlet senam ritmik Indonesia sampai saat ini belum memperlihatkan prestasi yang memuaskan, terutama dalam ajang olahraga senam ritmik baik regional maupun internasional. Untuk meningkatkan prestosi cabang olahraga senam ritmik, diperlukan peningkatan pada komponen kebugaran jasmani yang predominan pada cabang olahraga tersebut.

Senam ritmik merupakan senam yang dikembangkan dari senam irama konvensional. Cabang olahraga ini menggunakan alat-alat seperti bola, pita, tali, simpai, dan gada, dimana penggunaan alat-alat tersebut digabungkan dengan berbagai gerak terencana dan menjadi suatu kesatuan gerak yang harmonis.

Sedangkan kebugaran jasmani adalah kemampuan seorang atlet untuk memenuhi aktivitas fisik yang dituntut oleh cabang olahraga yang ditekuni, dalam hal ini yaitu cabang olahraga senam ritmik, tanpa mengalami kelelahan yang berlebihan. Dengan demikian tentu saja kebugaran jasmani sangat berpengaruh terhadap prestasi olahraga yang bersangkutan. Setiap cabang olahraga memiliki komponen kebugaran jasmani yang predominan, dan untuk cabang olahraga senam ritmik, komponenkomponen tersebut diantaranya adalah daya tahan jantung paru, daya tahan otot, kekuatan otot, daya ledak otot, serta kelentukan. Untuk mencapai prestasi yang baik, seorang atlet harus menjaga agar komponen-komponen di atas selalu berada dalam keadaan prima.

Untuk meningkatkan komponen kebugaran jasmani yang predominan pada cabang senam ritmik, perlu dilakukan latihan-latihan yang dapat menguatkan komponen kebugaran tersebut. Atlet senam ritmik yang akan mewakili Kota Bandung telah mempersiapkan diri untuk bertanding padaajang Pekan Olahraga Daerah (PORDA) XI pada tahun 2010 mendatang. Untuk mengetahui kondisi fisik atlet tersebut maka dilakukan pemeriksaan komponen kebugaran jasmani yang predominan untuk cabang olah raga senam ritmik dan kemudian hasilnya dikelompokkan menurut Standar KONI Pusat.

Dengan dilakukannya penelitian ini maka akan didapatkan gambaran mengenai kondisi fisik atlet senam ritmik Kota Bandung saat ini. Hasil penelitian diharapkan dapat member masukan bagi atlet, pelatih, dan induk cabang olahraganya sebagai bahan evaluasi dalam rangka penyusunan program latihan selanjutnya.

\section{METODE}

Subjek penelitian merupakan atlet senam ritmik Kota Bandung yang berjumlah 9 orang, berjenis kelamin perempuan dengan usia antara 10-18 tahun. Sebelum dilakukan penelitian terhadap subjek penelitian, terlebih dahulu diberikan penjelasan mengenai jenis penelitian, prosedur penelitian, kegunaan penelitian, tempat dilakukannya penelitian, waktu yang diperlukan untuk melakukan penelitian, faktor-faktor apa saja yang akan mempengaruhi penelitian, serta penyuluhan mengenai pentingnya pemeriksaan kebugaran jasmani yang predominan untuk cabang olahraga senam yaitu daya tahan jantung paru, daya tahan otot, kekuatan otot, daya ledak otot, dan kelentukan. Namun karena usia subjek yang masih dibawah 20 tahun, sulit untuk dilakukan pemeriksaan jantung paru sehingga komponen kebugaran jasmani yang diperiksa adalah daya tahan otot, kekuatan otot, daya ledak otot, dan kelentukan.

Adapun kriteria inklusi bagi subjek penelitian adalah:

1. telah mengikuti latihan minimal 6 bulan

2. berlatih rutin minimal 3 kali seminggu

3. memiliki derajat kesehatan yang baik

Tipe penelitian survai deskriptif di bidang Ilmu Faal Olahraga ini untuk meneliti profil daya tahan otot lokal, kekuatan otot, daya ledak otot, dan kelentukan pada atlet senam ritmik kota Bandung dibandingkan dengan Standar Fisik KONI Pusat.

Variabel penelitian dalam penelitian ini meliputi:

1. Variabel Respon

- Daya tahan otot, yaitu kemampuan otot untuk mempertahankan gerakan repetisi dengan melawan resistansi selama periode waktu tertentu. Pengukuran daya tahan otot lengan dan bahu dilakukan dengan cara melakukan push-up sedangkan daya tahan otot perut dilakukan dengan cara melakukan sit-up.

- Kekuatan otot, yaitu besar kekuatan yang dapat dihasilkan selama kontraksi otot berlangsung. Pengukuran kekuatan otot tangan, otot lengan dan bahu, otot punggung dan otot tungkai dilakukan dengan menggunakan alat dinamometri genggam, dinamometri tangan, dinamometri punggung dan dinamometri tungkai.

- Daya ledak otot, yaitu kemampuan otot untuk mengerahkan kekuatan maksimal dalam waktu yang sangat cepat. Pengukuran daya ledak otot lengan dan bahu dilakukan dengan cara melempar 
medicine ball, sedangkan pengukuran daya ledak otot tungkai dilakukan dengan cara melakukan lompatan vertikal.

- Kelentukan, yaitu luas pergerakan pada sendi tubuh, atau dapat pula disebut resistansi sendi dalam melakukan pergerakan. Pengukuran dilakukan dengan menggunakan sit and reach test,dimana hasilnya akan diukur menggunakan alat flexometer.

2. Variabel Kontrol

- Karakteristik fisik

- Usia (tahun)

- Berat Badan (kg)

- Tinggi Badan $(\mathrm{cm})$

- Indeks Massa Tubuh $\left(\mathrm{kg} / \mathrm{m}^{2}\right)$

- Karakteristik fisiologis

- Denyut nadi istirahat (denyut/menit)
- Tekanan darah sistolik dan diastolik pada saat istirahat $(\mathrm{mmHg})$

Dari penelitian maka akan didapatkan data mengenai daya tahan otot lokal yaitu otot lengan dan bahu serta perut, kemudian didapatkan pula kekuatan otot tangan, otot lengan dan bahu, otot punggung, otot tungkai, daya ledak otot lengan dan bahu serta tungkai, juga kelentukan pada atlet senam ritmik kota Bandung. Data-data tersebut kemudian akan dikelompokkan menjadi kategori yang sesuai menurut Standar KONI Pusat.

\section{HASIL}

Pengukuran karakteristik fisik-fisiologis atlet senam ritmik kota Bandung yang terdiri dari usia (tahun), berat badan $(\mathrm{kg})$, tinggi badan $(\mathrm{cm})$, Indeks Massa Tubuh $(\mathrm{kg} / \mathrm{m} 2)$, Nadi Istirahat (denyut/menit), dan Tekanan Darah Istirahat Sistolik $(\mathrm{mmHg})$ dan Diastolik (mmHg) dapat dilihat pada tabel 1 di bawah ini.

Tabel 1 Karakteristik Fisik-Fisiologis Atlet Senam Ritmik Kota Bandung

\begin{tabular}{|c|c|c|c|c|c|c|c|}
\hline \multirow{2}{*}{ No } & \multirow{2}{*}{ Usia(tahun) } & \multirow{2}{*}{$\begin{array}{l}\text { BB } \\
(\mathrm{kg})\end{array}$} & \multirow{2}{*}{$\mathrm{TB}(\mathrm{cm})$} & \multirow{2}{*}{$\operatorname{IMT}(\mathrm{kg} / \mathrm{m} 2)$} & \multirow{2}{*}{$\begin{array}{l}\text { Nadi Istirahat } \\
\text { (denyut/menit) }\end{array}$} & \multicolumn{2}{|c|}{$\begin{array}{c}\text { Tekanan Darah Istirahat } \\
\text { (mmHg) }\end{array}$} \\
\hline & & & & & & Sistolik & Diastolik \\
\hline 1. & 10 & 29,2 & 139,4 & 15 & 108 & 100 & 60 \\
\hline 2. & 12 & 40,2 & 154,8 & 17 & 78 & 110 & 70 \\
\hline 3. & 13 & 43,7 & 153,5 & 19 & 92 & 120 & 80 \\
\hline 4. & 13 & 38,9 & 149 & 18 & 96 & 100 & 70 \\
\hline 5. & 14 & 32,1 & 153,5 & 18 & 96 & 110 & 70 \\
\hline 6. & 14 & 41,6 & 153 & 18 & 96 & 100 & 70 \\
\hline 7. & 15 & 45,5 & 153,6 & 19 & 72 & 110 & 70 \\
\hline 8. & 17 & 50,9 & 155,2 & 21 & 88 & 110 & 70 \\
\hline 9. & 18 & 50,4 & 154 & 21 & 96 & 120 & 70 \\
\hline $\mathbf{X}$ & 14 & 42,5 & 151,78 & 18,35 & 91,33 & 108,89 & 70 \\
\hline SD & 2,45 & 6,51 & 4,97 & 2,00 & 10,77 & 7,82 & 5,00 \\
\hline Kete & an: & $\begin{array}{l}: \text { Bera } \\
T: \text { Ind } \\
: \text { Stan }\end{array}$ & $\begin{array}{l}\text { adan } \\
\text { Massa Tu } \\
\text { Deviasi }\end{array}$ & & $\begin{array}{l}\text { TB: Tinggi Badan } \\
\text { X : rata-rata }\end{array}$ & & \\
\hline
\end{tabular}

Derajat Profil Daya Tahan Otot Lengan dan Bahu serta Perut pada Atlet Senam Ritmik Kota Bandung Menurut Standar KONI Pusat

Data mengenai daya tahan otot lengan dan bahu serta perut pada atlet senam ritmik Kota Bandung tercantum pada lampiran 5. Dari data tersebut maka akan dikelompokkan menurut Standar KONI Pusat kemudian dihitung persentasinya. Hasilnya dapat dilihat pada Grafik 1 dan 2. 




Grafik 1 Persentasi Derajat Profil Daya Tahan Otot Lengan dan Bahu pada Atlet Senam Ritmik Kota Bandung Menurut Standar KONI Pusat

Dari Grafik 1 didapatkan hasil bahwa semua atlet otot lengan dan bahu yang berada dalam kategori senam ritmik kota Bandung memiliki daya tahan sempurna menurut Standar KONI Pusat.

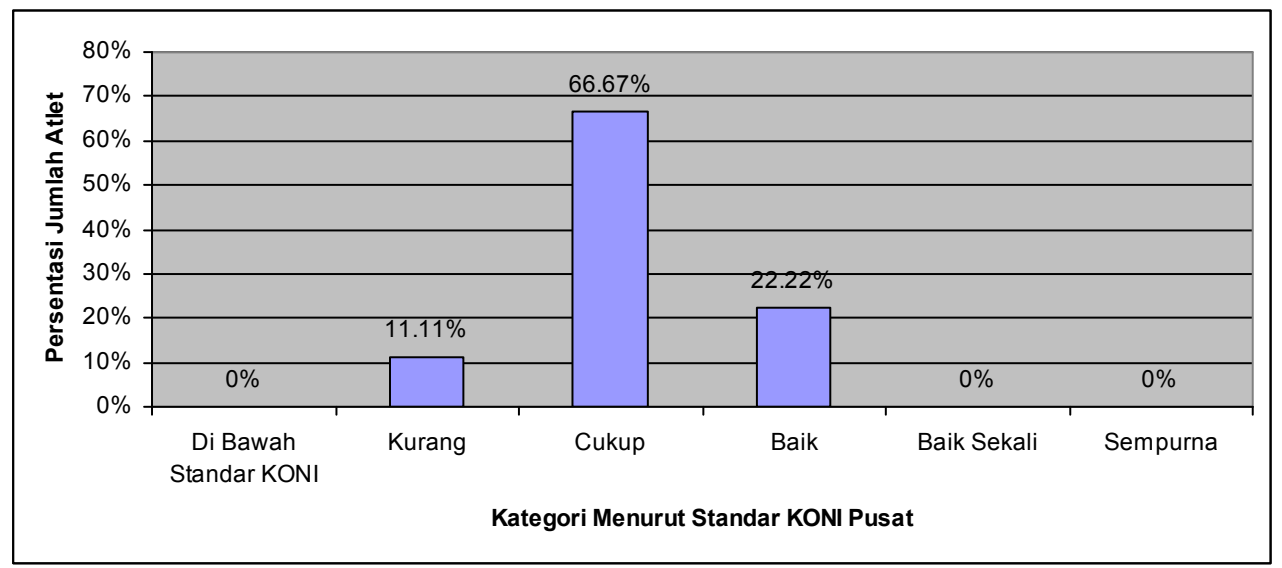

Grafik 2 Persentase Derajat Profil Daya Tahan Otot Perut pada Atlet Senam Ritmik Kota Bandung Menurut Standar KONI Pusat

Dari Grafik 2 didapatkan hasil bahwa sebagian besar atlet senam ritmik Kota Bandung, yaitu sebanyak $66.67 \%$, memiliki daya tahan otot perut yang berada dalam kategori cukup sedangkan $11.11 \%$ masih berada pada kategori kurang dan hanya $22.22 \%$ yang berada pada kategori baik.

Derajat Profil Kekuatan Otot tangan, Kekuatan Otot Lengan dan Bahu, Kekuatan Otot Punggung,
Kekuatan Otot Tungkai pada Atlet Senam Ritmik Kota Bandung Menurut Standar KONI Pusat

Data mengenai kekuatan otot tangan, kekuatan otot lengan dan bahu, kekuatan otot punggung, dan kekuatan otot tungkai pada atlet senam ritmik Kota Bandung tercantum pada lampiran 4. Dari data tersebut maka akan dikelompokkan menurut Standar KONI Pusat kemudian dihitung persentasinya. Hasilnya dapat dilihat pada Grafik 3 - 6 . 


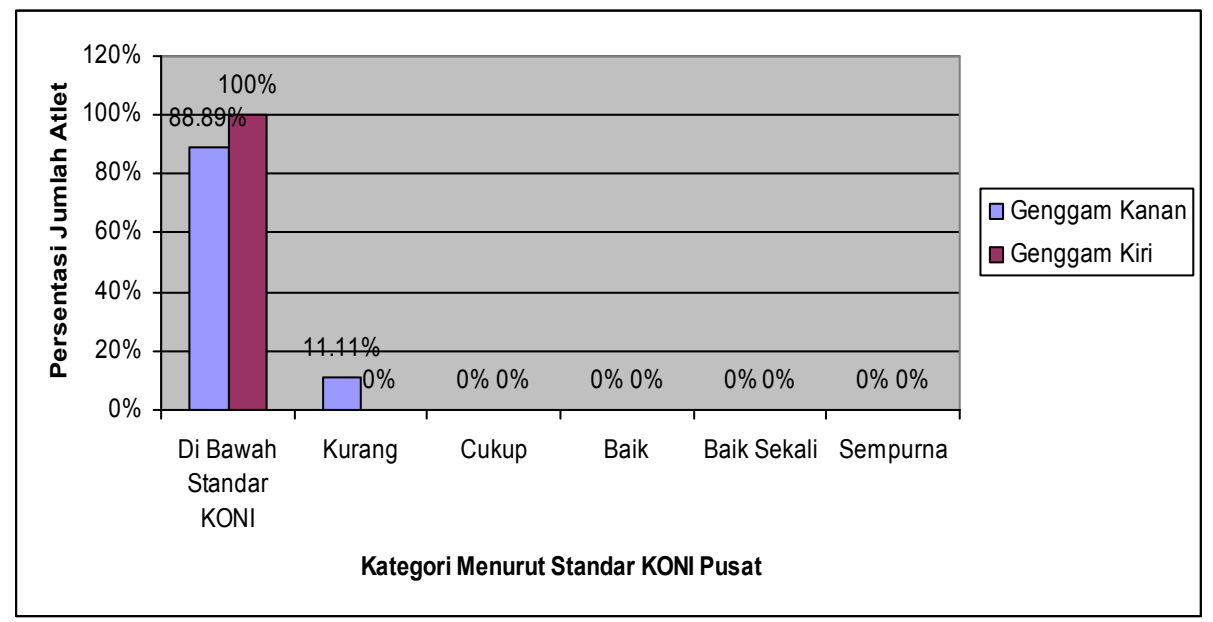

Grafik 3 Persentasi Derajat Profil kekuatan Otot Tangan pada Atlet Senam Ritmik Kota Bandung Menurut Standar KONI Pusat

Dari Grafik 3 didapatkan hasil bahwa sebanyak $88.89 \%$ atlet senam ritmik Kota Bandung memiliki kekuatan tangan kanan yang masih di bawah Standar KONI Pusat, dan sebanyak $11.11 \%$ termasuk ke dalam kategori kurang. Sedangkan untuk kekuatan tangan kiri didapatkan bahwa semua atlet senam ritmik Kota Bandung masih berada di bawah Standar KONI Pusat.

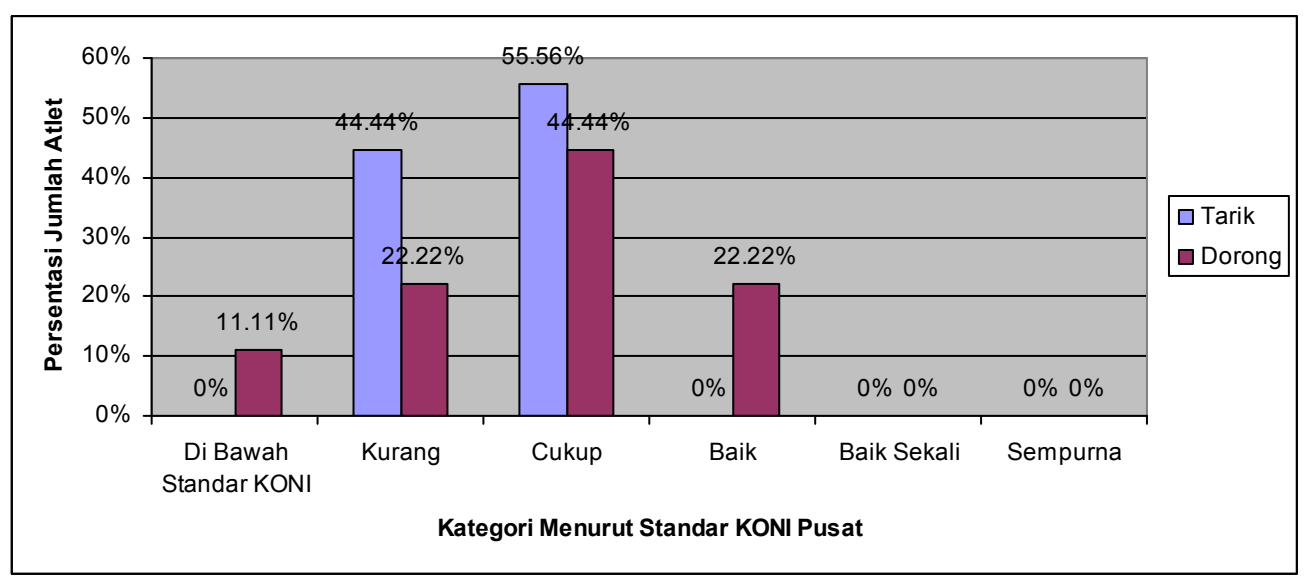

Grafik 4 Persentasi Derajat Profil Kekuatan Otot Lengan dan Bahu pada Atlet Senam Ritmik Kota Bandung Menurut Standar KONI Pusat

Dari Grafik 4 didapatkan hasil bahwa kurang lebih setengah dari atlet senam ritmik Kota Bandung, yaitu sebanyak 55,56\%, memiliki kekuatan otot lengandan bahu untuk tarikan yang termasuk kedalam kategori cukup menurut Standar KONI Pusat sedangkan sisanya yaitu sebanyak $44.44 \%$ termasuk kedalam kategori kurang.
Mengenai kekuatan otot lengan dan bahu untuk dorongan, didapatkan bahwa sebagian besar, yaitu sebanyak $44.44 \%$, termasuk kedalam kategori cukup sedangkan sisanya termasuk kedalam kategori baik (22.22\%), kurang $(22.22 \%)$, dan masih di bawah Standar KONI Pusat (11.11\%). 


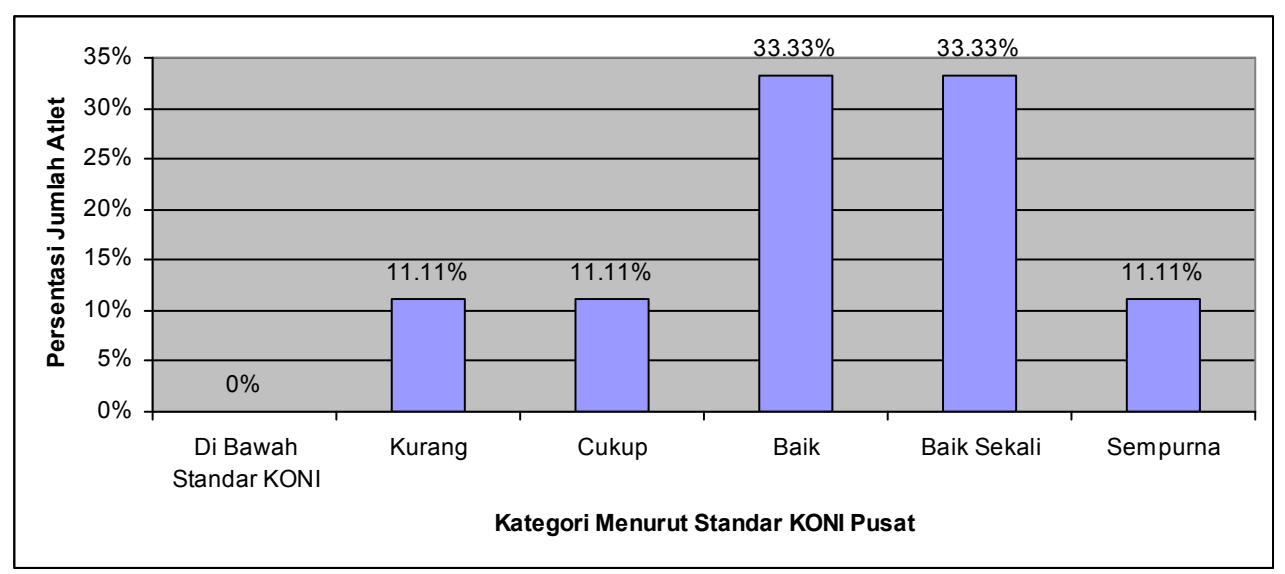

Grafik 5 Persentasi Derajat Profil Kekuatan Otot Punggung pada Atlet Senam Ritmik Kota Bandung Menurut Standar KONI Pusat

Dari Grafik 5 didapatkan bahwa sebanyak $33,33 \%$ dari atlet senam ritmik Kota Bandung memiliki kekuatan otot punggung yang termasuk ke dalam kategori baik dan baik sekali menurut Standar
KONI Pusat, sedangkan sisanya termasuk ke dalam kategori kurang (11.11\%), cukup (11.11\%), dan sempurna $(11.11 \%)$.

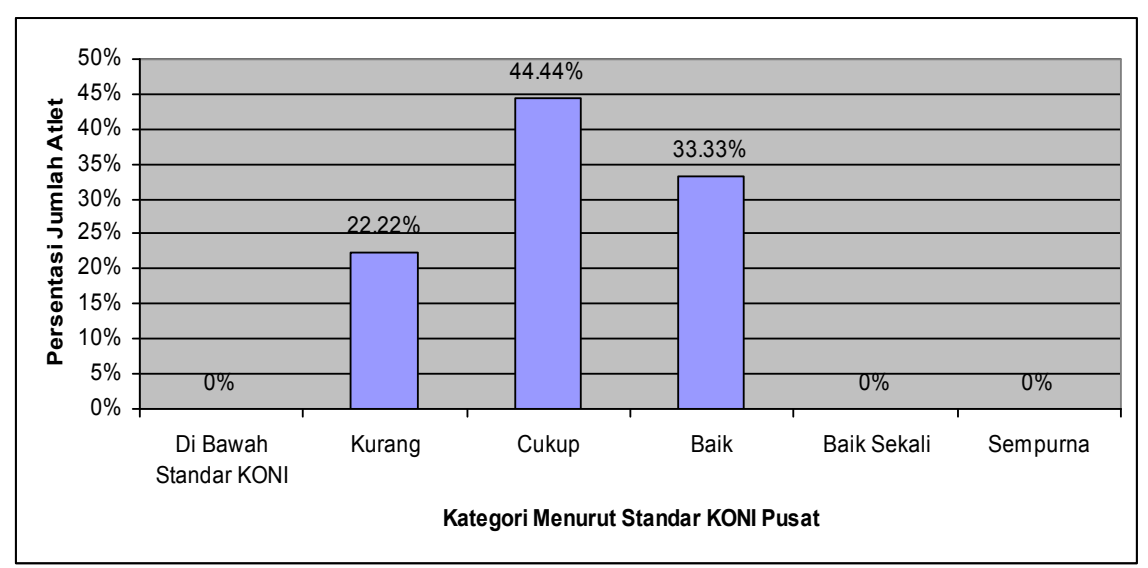

Grafik 6 Persentasi Derajat Profil Kekuatan Otot Tungkai pada Atlet Senam Ritmik Kota Bandung Menurut Standar KONI Pusat

Dari Grafik 6 didapatkan bahwa sebagian besar atlet senam ritmik Kota Bandung memiliki kekuatan otot tungkai yang termasuk ke dalam kategori cukup menurut Standar KONI Pusat, yaitu sebanyak $44.44 \%$, sedangkan sisanya termasuk ke dalam kategori baik (33.33\%) dan kurang (22.22\%).
Derajat Profil Daya Ledak Otot Lengan dan Bahu serta Tungkai pada Atlet Senam Ritmik Kota Bandung Menurut Standar KONI Pusat

Data mengenai daya ledak otot lengan dan bahu serta tungkai pada atlet senam ritmik Kota Bandung tercantum pada lampiran 5. Dari data tersebut maka akan dikelompokkan menurut Standar KONI Pusat kemudian dihitung persentasinya. Hasilnya dapat dilihat pada Grafik 7. 


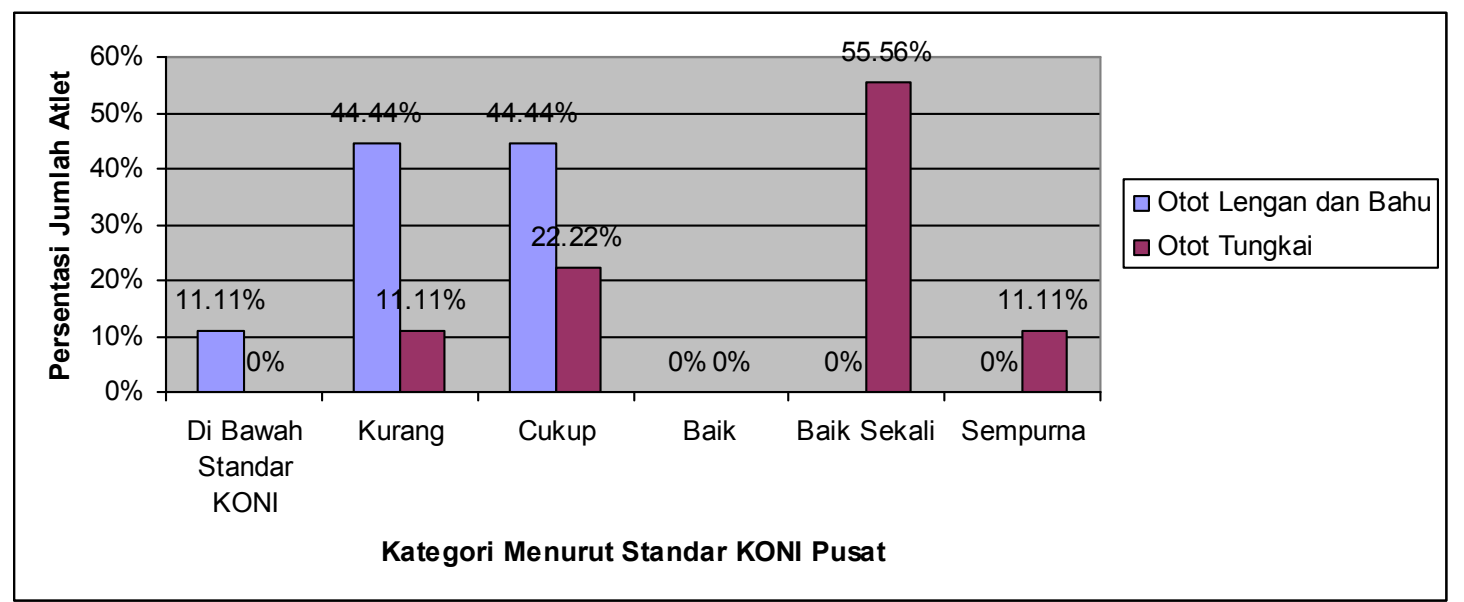

Grafik 7 Persentasi Derajat Profil Daya Ledak Otot pada Atlet Senam Ritmik Kota Bandung Menurut Standar KONI Pusat

Dari Grafik 7 didapatkan bahwa daya ledak otot lengan dan bahu yang dimiliki oleh atlet senam ritmik Kota Bandung termasuk ke dalam kategori kurang (44.44\%) dan cukup (44.44\%), sedangkan sisanya masih berada di bawah Standar KONI Pusat.
Untuk daya ledak otot tungkai didapatkan bahwa sebagian besar $(55.56 \%)$ berada dalam kategori baik sekali, sedangkan sisanya termasuk ke dalam kategori cukup (22.22\%), sempurna (11.11\%) dan kurang (11.11\%).

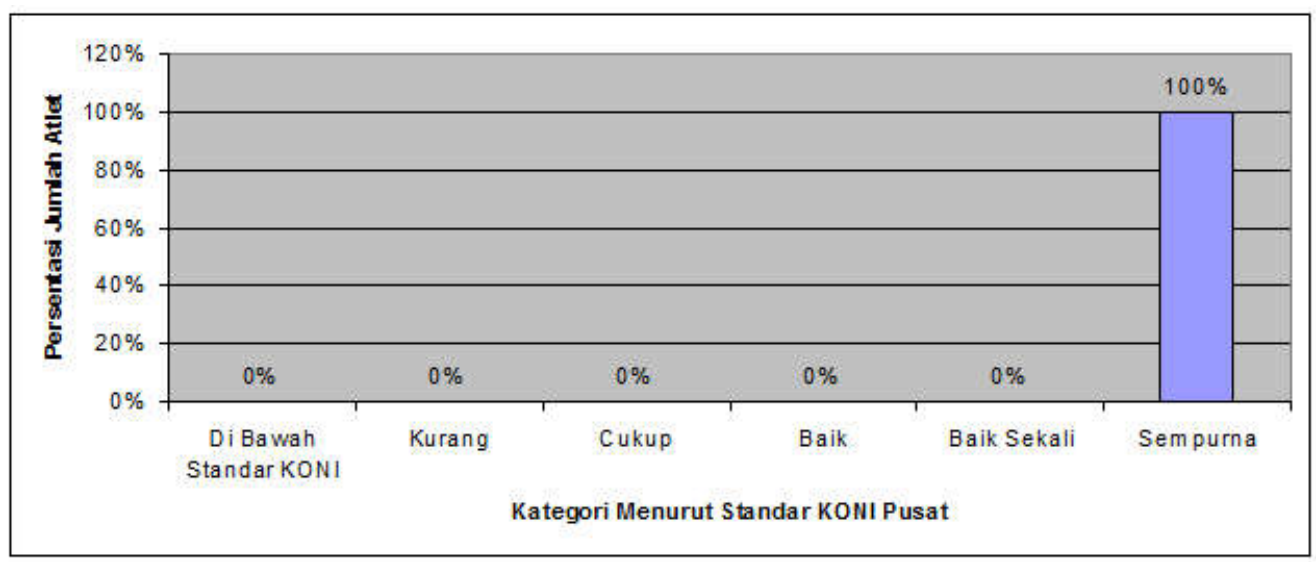

Grafik 8 Persentasi Derajat Profil Kelentukan pada Atlet Senam Ritmik Kota Bandung Menurut Standar KONI Pusat

Data mengenai kelentukan pada atlet senam ritmik Kota Bandung tercantum pada lampiran 5. Dari data tersebut maka akan dikelompokkan menurut Standar KONI Pusat kemudian dihitung persentasinya. Hasilnya dapat dilihat pada Grafik 8. Derajat Profil Kelentukan Atlet Senam Ritmik Kota Bandung Menurut Standar Fisik KONI Pusat

Dari Grafik 8 didapatkan hasil bahwa semua atlet senam ritmik kota Bandung memiliki kelentukan yang termasuk ke dalam kategori sempurna menurut Standar KONI Pusat.

\section{DISKUSI}

Derajat Profil Daya Tahan Otot Lengan dan Bahu serta Perut pada Atlet Senam Ritmik Kota Bandung Menurut Standar KONI Pusat

Dari Grafik 1 didapatkan hasil bahwa semua atlet senam ritmik Kota Bandung memiliki daya tahan otot lengan dan bahu yang berada dalam kategori sempurna menurut Standar KONI Pusat. Hal ini tidak sesuai dengan profil kekuatan otot lengan dan bahu yang dimiliki atlet tersebut, dimana didapatkan bahwa sebagian besar berada dalam kategori cukup, baik untuk tarikan maupun dorongan. Berdasarkan pengamatan peneliti, hasil 
yang tidak sesuai ini kemungkinan disebabkan oleh kurang telitinya pemeriksa dalam melakukan pencatatan hasil pemeriksaan fisik pada subjek.

Sedangkan dari Grafik 2 didapatkan hasil bahwa untuk daya tahan otot perut, sebagian besar atlet senam ritmik Kota Bandung berada dalam kategori cukup, namun masih ada sebagian atlet yang masih berada dalam kategori kurang. Hal ini mengindikasikan bahwa latihan untuk melatih daya tahan otot perut yang dilakukan belum memadai untuk mencapai hasil yang maksimal.

Derajat Profil Kekuatan Otot Tangan, Kekuatan Otot Lengan dan Bahu, Kekuatan Otot Punggung, Kekuatan Otot Tungkai pada Atlet Senam Ritmik Kota Bandung Menurut Standar KONI Pusat

Dari Grafik 3 didapatkan hasil bahwa sebagian besar atlet senam ritmik Kota Bandung memiliki kekuatan tangan yang masih berada di bawah Standar KONI Pusat, dan hal ini mengindikasikan kurangnya latihan kekuatan tangan yang telah dilakukan.

Dari Grafik 4 didapatkan hasil bahwa sebagian besar atlet senam ritmik Kota Bandung memiliki kekuatan otot lengan dan bahu yang termasuk ke dalam kategori cukup. Namun masih ada sebagian yang berada dalam kategori kurang, dan ada pula yang masih berada di bawah Standar KONI Pusat. Hal ini mengindikasikan bahwa latihan untuk melatih kekuatan lengan dan bahu yang telah dilakukan masihkurang.

Dari Grafik 5 didapatkan bahwa sebagian besar atlet senam ritmik Kota Bandung memiliki kekuatan otot punggung yang termasuk ke dalam kategori baik dan baik sekali, dan sisanya berada dalam kategori kurang, cukup, dan ada pula yang termasuk ke dalam kategori sempurna. Derajat profil kekuatan otot punggung yang bervariasi tersebut mengindikasikan bahwa latihan kekuatan otot punggung yang telah dilakukan kurang sesuai dengan kebutuhan masing-masing atlet.

Dari Grafik 6 didapatkan bahwa sebagian besar atlet senam ritmik Kota Bandung memiliki kekuatan otot tungkai yang termasuk ke dalam kategori cukup, namun masih ada yang berada dalam kategori kurang. Hal ini mengindikasikan kurangnya latihan kekuatan tungkai yang telah dilakukan.

Derajat Profil Daya Ledak Otot Lengan dan Bahu serta Daya Ledak Otot Tungkai pada Atlet Senam Ritmik Kota Bandung Menurut Standar KONI Pusat

Dari Grafik 7 didapatkan bahwa sebagian besar daya ledak otot lengan dan bahu yang dimiliki oleh atlet senam ritmik Kota Bandung termasuk ke dalam kategori kurang dan cukup, serta masih ada yang berada di bawah Standar KONI Pusat. Hal ini sesuai dengan profil kekuatan lengan dan bahu yang ada, dan mengindikasikan kurangnya latihan untuk kekuatan otot lengan dan bahu turut berpengaruh kepada kurang baiknya kemampuan daya ledak otot lengan dan bahu pada subjek.

Sedangkan untuk daya ledak otot tungkai didapatkan bahwa sebagian besar berada dalam kategori baik sekali, namun ada pula sebagian yang termasuk ke dalam kategori kurang. Dilihat dari profil kekuatan otot tungkai yang ada, tampak bahwa kekuatan otot tersebut kurang berpengaruh kepada kemampuan daya ledak otot tungkai pada subjek. Ditinjau dari kepustakaan, dimana daya ledak otot dipengaruhi oleh kombinasi dari kekuatan otot dan kecepatan, maka kemungkinan latihan kecepatan yang dilakukan sudah memadai sehingga dapat meningkatkan performa subjek. Namun karena masih ada sebagian dari subjek yang berada dalam kategori kurang, hal ini mengindikasikan bahwa latihan yang telah dilakukan kurang sesuai dengan kebutuhan masing-masing atlet.

\section{Derajat Profil Kelentukan Atlet Senam Ritmik Kota Bandung Berdasarkan Standar KONI Pusat}

Dari Grafik 8 didapatkan hasil bahwa semua atlet senam ritmik Kota Bandung memiliki kelentukan yang termasuk ke dalam kategori sempurna menurut Standar KONI Pusat. Menurut pengamatan peneliti hal ini disebabkan karena banyaknya porsi latihan kelentukan yang dilakukan oleh subjek tersebut.

\section{KESIMPULAN}

Berdasarkan hasil penelitian dan pembahasan hasil penelitian, dapat diambil kesimpulan sebagai berikut:

1. Profil daya tahan otot pada atlet senam ritmik Kota Bandung menurut Standar KONI Pusat:

- Daya tahan otot lengan dan bahu seluruhnya termasuk kedalam kategori sempurna, namun hal ini diragukan karena hal-hal yang telah disebutkan sebelumnya.

- Daya tahan otot perut sebagian besar termasuk kedalam kategori cukup, namun ada pula yang berada dalam kategori kurang.

2. Profil kekuatan otot pada atlet senam ritmik Kota Bandung menurut Standar KONI Pusat:

- Kekuatan otot tangan sebagian besar masih berada di bawah Standar KONI Pusat.

- Kekuatan otot lengan dan bahu sebagian besar termasuk kedalam kategori cukup, namun ada pula yang berada dalam kategori kurang, bahkan di bawah Standar KONI Pusat. 
- Kekuatan otot punggung sebagian besar termasuk kedalam kategori baik dan baik sekali, namun ada pula yang berada dalam kategori kurang.

- Kekuatan otot tungkai termasuk kedalam kategoricukup, namun ada pula yang berada dalam kategori kurang.

3. Profil daya ledak otot pada atlet senam ritmik Kota Bandung menurut Standar KONI Pusat:

- Daya ledak otot lengan dan bahu sebagian besar termasuk kedalam kategori kurang dan cukup, namun ada pula yang berada di bawah Standar KONI Pusat.

- Daya ledak otot tungkai sebagian besar termasuk kedalam kategori baik sekali, namun ada pula yang berada dalam kategori kurang.

4. Profil kelentukan pada atlet senam ritmik Kota Bandung menurut Standar KONI Pusat:

- Kelentukan seluruhnya termasuk kedalam kategori sempurna.

\section{DAFTAR PUSTAKA}

1. Mahendra DA. 2003. Pembelajaran Permainan Senam. Departemen Pendidikan Nasional. Jakarta: Direktorat Jendral Pendidikan Dasar dan Menengah.

2. Watson AWS. 1983. Physical Fitness \& Athletic Performance. London and New York: Longman.

3. Werner PH. 2003. Teaching Children Gymnastics, 2 ed, Human kinetics. London: Longman.

4. Hidayat I. 1996. Senam : Diktat. Bandung: FPOKIKIP.

5. Harsono. 1988. Coaching dan Aspek-aspek Psikologis dalam Coaching. Jakarta: CV Tambak Kesuma.

6. Newton R.V. MAJ, Humpries B.J., Wilson G.J., Kraemor W.J., Hakkinen K. 1997. Influence of Load and Stretch Shortening Cycle on the Kinematics, Kinetics and Muscle Activation That Occurs During Explosive Upper-body Movements. Eur JAppl Phyiol Occu Physiol. 75(4):333-42.

7. Donald E. Hartig JMH. 1999. Increasing Hamstring Flexibility Decrease Lower Extremity Overuse Injuries in Military Basic Trainees. The American J Of Sports and Med. 27(2):173-6.
8. Dick FW. 2002. Sports Training Principle. London: A\&C Black Publisher Ltd.

9. Werner W. K. Hoeger SAH. 2005. Lifetime Physical Fitness and Wellness. $8^{\text {th }}$ Ed. Belmont: Thomson Wadworth.

10. Alway S.E. SDG, MacDougall J.D. 1990. Twitch contractile adaptations are not dependent on the intensity of isometric exercise in the human triceps surae. Eur $J$ Appl Physiol Occup Physiol. 60(5):346-52.

11. D.A. Jones OMR. 1987. Human muscle strength training: the effects of three different regimens and the nature of the resultant changes. The $J$ of Physiol. 391:1-11.

12. Guyton A.C HJE. 1995. Textbook of Medical Physiology, 9th Ed. Philadelphia: Saunders.

13. Witvrouw Erik DL, Asselmen Peter, Cambier Dirk. 2003. Muscle Flex as A Risk Factor for Developing Muscle Injuries in Male Professional Soccer Players: A Prospective Study The American J of Sport Med. 31(1):41-6.

14. Bompa TO. 1999. Periodization: Theory and Methodology of Training, 4th Ed. Idaho: Human Kinetics. 